\title{
HUBUNGAN SELF EFFICACY DENGAN QUALITY OF LIFE PADA PASIEN SESUDAH STROKE
}

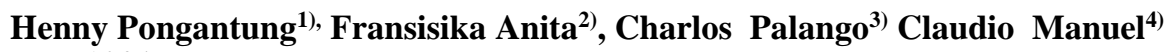 \\ 1,2,3,4 Program Studi Sarjana Keperawatan STIK Stella Maris, Makassar \\ e-mail: hennypongantung@gmail.com
}

\begin{abstract}
Stroke is a disease that can cause the first number of disabilities and their events occur suddenly, which can cause severe disability or death. The disability has an effect on the psychological state so that it can experience depression with symptoms of feeling helpless, ashamed of the situation which can result in quality of life decreased. Many factors affect the quality of life, one of which is self efficacy. Self efficacy is the most important factor that is very influential on stroke patients. Someone with high self efficacy can increase higher motivation so they have the desire to recover quickly. This study aims to determine the relationship between self efficacy and quality of life in patients after stroke. This research is an observational analytic with study cross sectional design.The sampling method using non-probability sampling techniques through consecutive sampling, amounting to 76 respondents. The instrument used was in the form of a questionnaire, the test used in this study was the statistical test chi-square because there was a value of count $<5$ and anvalue of expected count $>20 \%$ then continued with the merging of cells so that the table changed to $2 \times 2$ and the value of $p=0,000$ was obtained with the level significance of $\alpha=0.05$ which is read in Fisher's Exact Test. This shows that the value of $p<\alpha$ means that there is a relationship of self efficacy with quality of life in patients after stroke in the South Sulawesi Provincial Hospital. It is expected that patients after stroke have high self efficacy so they can act in a positive direction in order to improve their health status so that the quality of life also increases
\end{abstract}

Keywords: Self Efficacy, Quality Of Life, Stroke 


\section{PENDAHULUAN}

Gaya hidup seseorang terutama di perkotaan mialnya makan berlebihan, aktifitas kurang, bekerja berlebihan, serta kurang makanan berserat adalah faktor-faktor yang dapat mengakibatkan penyakit stroke (Anita dan Pongantung , 2018). Stroke diakibatkan oleh karena kondisi proses penurunan fungsi jaringan tubuh termasuk otak oleh karena bertambahnya umur (Pertamita, 2017).

Menurut data World Health Organisation (2016), hampir lima belas juta jiwa mengalami stroke di dunia. Hal ini merupakan masalah besar, karena dapat menyerang siapa saja dan dapat terjadi secara tiba-tiba dan sekitar 6,6 juta mengakibatkan kematian.

Prevalensi stroke di Indonesia menurut diagnosis tenaga medis pada populasi usia $\geq 15$ tahun urutan tiga teratas yaitu di Provinsi Kalimantan Timur 14,7\%, Provinsi Daerah Istimewa Yogyakarta $14,6 \%$, Provinsi Sulawesi Utara 14,2\%. Sedangkan untuk Provinsi Sulawesi Selatan pada posisi ke 17 sebesar 10,6\% (Riskesdas 2018). Hasil pendataan Penyakit tidak menular Dinas Kesehatan Provinsi Sulawesi Selatan tahun 2015 bahwa ditemukan stroke pasien lama sebanyak 2.623 kasus yaitu 606 kasus di puskesmas dan 2.017 kasus di Rumah Sakit (Profil Kesehatan Provinsi Sulawesi Selatan Tahun 2015) dan prevalence pasien stroke yang dirawat di Stroke Center RSKD Provinsi Sulawesi Selatan pada tahun 2018 berjumlah 573 orang.

Stroke merupakan masalah berat bagi pasien, karena sesudah stroke pasien bakal menyandang kelemahan anggota tubuh serta keterbatasan melakukan kegiatan sehari hari seperti sebelum sakit. Pasien sering mengeluh dan merasa bersalah, ini adalah tanda bahwa pasien stroke mengalami penurunan harga diri (Pertamita, 2017). Masniah, (2017) berpendapat bahwa penyintas stroke akan menjalani kehidupan sehari hari dengan kelemahan fisik dalam waktu yang lama dan berdampak pada masalah kejiwaan , sosial maupun spiritual sehingga kualitas hidup akan menurun .

Kerusakan struktur jaringan otak mengakibatkan masalah bentuk tubuh, penurunan fungsi anggota gerak , keterbatasan melakukan aktifitas dan ketidak berdayaan, kondisi ini menganggu psikologi penyintas stroke sehingga mereka merasa kehilangan peran dalam keluarga dan masyarakat, hal ini dapat memicu masalah efikasi diri (Yantik, 2014).

Self efficacy yaitu kemampuan diri yang dimiliki seseorang untuk mengerakan pikiran dan hati dalam bertindak mencapai harapan (Pertamita, 2017) selain factor dukungan sosial dan aspek psikologi hal ini turut mempengaruhi rasa percaya diri seseorang . Self efficacy yang tinggi membantu menurunkan stress karena perunahan kondisi fisik dan perubahan emosi pada pasien sesudah stroke. Untuk mengatasi hal ini dukungan keluarga terdekat dan mendampingi dalam melakukan kegiatan sehari akan meningkatkan kpercayaan diri, harga diri dan semangat pasien untuk sembuh (Yantik, 2014).

\section{METODE}

Rancangan Penelitian ini yaitu penelitian obsevasional analitik dengan desain penelitian cross sectional. Kegiatan ini dilaksanakan di Stroke Centre RSKD Provinsi Sulawesi Selatan pada Nopember 2019 sd February 2020. Cara pengambilan sampel dilakukan dengan teknik nonprobability sampling dengan cara consecutive sampling. Jumlah sampel yang diambil yaitu 76 responden dengan kriteria pasien dengan stroke lebih dari 3 bulan dan pertama kali serangan stroke, bisa membaca, dan kemampuan mendengar baik. Alat ukur dipenelitian ini adalah menggunakan instrument stroke self efficacy Quisioner (SSEQ) yang dikembangkan oleh Jones, F., \& Patridge, C. (2008) terdiri dari 13 pertanyaan yaitu pertanyaan tentang aktifitas terdiri delapan pertanyaan dan management diri lima pertanyaan. Dengan kategori self efficacy rendah: 0-13, self efficacy sedang: 14-26, self efficacy tinggi: 27-39. Kuesioner 
ini telah dilakukan uji cronbach's $\alpha \quad 0,90$ dan uji validitas $\mathrm{r}=0,803$ dan $\mathrm{p}<0,001$. (Jones \& Patridge, 2008). Dan kuesioner kedua menggunakan Stroke Specific quality of life dengan duapuluh pertanyaan serta mengunakan tingkat kategori Quality Of Life rendah: 20-60, Quality Of Life tinggi: 61-100. Kuesioner ini juga telah dilakukan uji cronbach's $\alpha \quad 0,92$ dan uji validitas $r=>3$ dan $\mathrm{p}<0,001$ (Hadiati, 2014).

Pengambilan data responden disesuaikan dengan kriteria inklusi dan waktu pengamabilan data dilaksanakan setelah melaksanakan fisioterapi, namun sebelum kuesioner diberikan dijelaskan sebelumnya tentang tujuan, dan proses penelitian. Persetujuan pengisian kusioner diperoleh atas dasar sukarela dari responden oleh karena penelitian ini hanya melibatkan pengumpulan informasi, tidak ada risiko yang berat yang akan berdampak langsung kepada responden. Jika responden tidak setuju makan dapat menolak untuk ikut dalam penelitian ini. Namun, peserta dijelaskan bahwa informasi yag diberikan dapat membantu peneliti untuk merencanakan strategi yang efektif untuk perawatan pasien stroke dan memajukan profesi keperawatan.

Untuk memastikan kerahasiaan, peneliti memberikan kode untuk setiap kuesioner dan menginterpretasi hasil kedua kuesioner dan dicatat dalam formulir kuesioner lalu dimasukan dalam amplop, dan kemudian disegel.

\section{HASIL PENELITIAN}

Tabel 1 Distribusi Frekuensi Responden Berdasarkan Kelompok Umur, Jenis Kelamin, Pendidikan Terakhir, Lama Stroke, Pekerjaan

\begin{tabular}{ccc}
\hline Karakteristik & $\begin{array}{c}\text { Frekuensi } \\
(\mathrm{f})\end{array}$ & $\begin{array}{c}\text { Persentase } \\
(\%)\end{array}$ \\
\hline Kelompok Umur & & \\
36-45 Tahun & 2 & 2,6 \\
46-55 Tahun & 12 & 15,8 \\
56-65 Tahun & 48 & 63,2 \\
$>$ 65 Tahun & 14 & 18,4 \\
\hline Jenis Kelamin & & \\
Laki-laki & 38 & 50,0 \\
Perempuan & 38 & 50,0 \\
\hline Pendidikan & & \\
Terakhir & & \\
SD & 14 & 18,4 \\
SMP & 24 & 31,6 \\
SMA/STM & 34 & 44,7 \\
S1 & 4 & 5,3 \\
\hline Lama Stroke & & \\
<1 Tahun & 56 & 73,7 \\
$>1$ Tahun & 20 & 26,3 \\
\hline Pekerjaan & & \\
Tidak Bekerja & 28 & 36,8 \\
Wiraswasta & 24 & 31,6 \\
PNS & 4 & 5,3 \\
\hline
\end{tabular}




\begin{tabular}{ccc} 
Petani & 6 & 7,9 \\
IRT & 14 & 18,4 \\
\hline Total & 76 & 100 \\
\hline
\end{tabular}

Tabel 2 Distribusi Frekuensi Responden Berdasarkan Self Efficacy

\begin{tabular}{ccc}
\hline Self Efficacy & $\begin{array}{c}\text { Frekuensi } \\
(f)\end{array}$ & $\begin{array}{c}\text { Persentase } \\
(\%)\end{array}$ \\
\hline Tinggi & 48 & 63,2 \\
Sedang & 16 & 21,0 \\
Rendah & 12 & 15,8 \\
\hline Total & 76 & 100 \\
\hline
\end{tabular}

Tabel 3 Distribusi Frekuensi Responden Berdasarkan Quality Of Life

\begin{tabular}{ccc} 
Quality Of Life & $\begin{array}{c}\text { Frekuensi } \\
(f)\end{array}$ & $\begin{array}{c}\text { Persentase } \\
(\%)\end{array}$ \\
\hline Sedang+Tinggi & 60 & 78,9 \\
Rendah & 16 & 21,1 \\
\hline Total & 76 & 100 \\
\hline
\end{tabular}

Tabel.4 Analisis Hubungan Self Efficacy dengan Quality Of Life Pada Pasien Sesudah Stroke

\begin{tabular}{|c|c|c|c|c|c|}
\hline \multirow{3}{*}{ Self Efficacy } & \multicolumn{4}{|c|}{ Quality Of Life } & \multirow{3}{*}{$P$} \\
\hline & Tinggi & Rendah & \multicolumn{2}{|c|}{ Total } & \\
\hline & $\mathrm{f} \%$ & $\%$ & $\mathrm{n}$ & $\%$ & \\
\hline Sedang + Tinggi & $\begin{array}{llll}\text { i } & 60 & 78,9 & 4\end{array}$ & 5,3 & 64 & 84,2 & 0,000 \\
\hline Rendah & $\begin{array}{lll}0 & 0,0 & 12\end{array}$ & 15,8 & 12 & 15,8 & \\
\hline Total & $\begin{array}{lll}60 & 78,9 & 16\end{array}$ & 21,1 & 76 & 100 & \\
\hline
\end{tabular}

Hasil penelitian ditemukan 76 pasien sesudah stroke memenuhi kriteria inklusi, terdapat pada rentang umur 56 - 65 tahun berjumlah $48(63,4)$ responden dengan sebagian besar berlatar belakang pendidikan sekolah menegah atas dan lama stroke kurang dari satu tahun $56(73,7 \%)$. Dan dari 65 responden dengan self efficacy tinggi dan memiliki quality of life tinggi berjumlah 60 (78,9\%) responden sedang Quality of life rendah terdapat $4(5,3 \%)$ responden.

Hasil uji statistic dengan uji $C h i$ Square tabel $3 \times 2$ yang dibaca pada pearson Chi Square, namun hasil uji statistik tersebut tidak bisa dibaca pada Pearson Chi Square karena ada nilai count $<5$ dan nilai expected count $>20 \%$, maka dilanjutkan dengan penggabungan sel sehingga tabelnya berubah menjadi $2 \times 2$ dan diperoleh nilai $\mathrm{p}=0,000$ dengan tingkat pemaknaan $\alpha=0,05$ yang dibaca di Fisher's Exact Test. Hasil ini Hal ini diperoleh bahwa nilai $\mathrm{p}<\alpha$ artinya ada hubungan antara self efficacy dengan quality of life pasien sesudah stroke di RSKD Provinsi Sulawesi Selatan.

\section{PEMBAHASAN}

1. Self efficacy pada pasien sesudah stroke Tabel diatas menunjukkan dominan responden memperoleh self 
efficacy yang tinggi.hasil ini sesuai dengan penelitian Ismatika \& Soleha (2017), yang menyebutkan self efficacy yang dimiliki pasien sesudah stroke dominan berada pada kelompok baik. Hasil yang sama ini juga ditemukan oleh Amalia (2016), yang mengemukanan self efficacy yang tinggi bisa meningkatkan kemampuan perawatan diri sendiri serta mengelola kondisi penyakitnya.

Menurut teori Jones \& Riazi (2011) dan Pertamita (2017), mengemukaan individu yang memiliki self efficacy yang baik akan memiliki kemampuan memotivasi dirinya melakukan sesuatu pekerjaan dengan baik, dan hal ini sebagai faktor penting untuk membantu mengatasi persolan yang ditemukan pasien stroke di dalam kehidupan mereka sehari-hari. Sedangkan Arsyta (2016) mengatakan, Self efficacy adalah kepercayaan individu mengenai potensi dirinya untuk melakukan sesuatu yang ingin dicapai dan mempunyai dampak pada masa depannya . Pandangan mengenai Self efficacy akan mempengaruhi kekuatan motivasi, kesuksesan dan keberhasilan individu. Self efficacy akan memberikan dorongan bagaimana individu berpikir, dan bertingkah laku.

Berdasarkan hasil observasi dan wawancara dengan responden, bahwa faktor pertama yang mempengaruhi pasien dengan self efficacy tinggi karena pasien memiliki harapan bahwa mereka dapat sembuh kembali melakukan aktifitas setiap hari, hal ini di tunjukkan dengan pasien dapat mengatasi rasa cemas, ketakutan dan kekhawatiran, pasien memiliki motivasi untuk sembuh yang dapat dilihat dari sikap dan juga usaha pasien yang terus menjalani terapiterapi dan juga pengobatan-pengobatan yang ada untuk proses kesembuhannya. Hasil penelitian ini sesuai dengan pendapat Rustika (2012), yang mengemukakan individu yang mempunyai self efficacy baik maka akan jarang mengalami stress, sedangkan seseorang yang mempunyai self efficacy yang rendah akan mengalami stress yang tinggi .

Faktor kedua yang mempengaruhi self efficacy yaitu usia. Rata-rata responden yang terkumpulkan sebagian besar pada tahap usia dewasa akhir dan lansia. Usia pada tahap ini telah mencapai masa kematangan psikologis, yang mana individu cenderung lebih menerima diri dengan apa adanya baik itu kelebihan maupun juga penyakit yang dideritanya, sehingga seseorang berusaha mencari jalan keluar apabila mengalami masalah. Pendapat ini sesuia dengan Howsepian \& Merluzzi (2009), yang mengemukakan umur berkorelasi secara signifikan dengan self efficacy. Seseorang pada tahap usia dewasa mempunyai self efficacy lebih tinggi dalam menghadapi masalah dalam kehidupan sehari hari , karena tahap ini sudah banyak mendapakan pengalaman dalam hidupnya dibandingkan usia muda.

Faktor ketiga yang mempengaruhi yaitu pendidikan. Dalam penelitian ini semua pasien sesudah stroke pernah menempuh pendidikan, dengan pendidikan terakhir terbanyak yaitu SMA/STM. Tingkat pendidikan pasien sangat penting dalam menyelesaikan permasalahan, artinya yaitu mempengaruhi perilaku khususnya pengetahuan dibidang kesehatan. Hasil penelitian ini sesuai dengan penelitian Latifah (2016), yang mengemukkan bahwa jenjang pendidikan seseorang dapat berpengaruh terhadap kemampuan menganalisis berita yang diperolah, sehingga individu menyakini keputusan yang dipilih dalam bertindak.

Pandangan peneliti bahwa pasien yang memiliki self efficacy yang tingi memiliki motivasi dan keyakinan yang besar untuk berhasil, sehingga rata rata pasien tersebut berusaha selalu untuk mentaati waktu latihan fisik untuk mencegah kelemahan fisik ,meningkatkan kemampuan berjalan, melakukan aktifitas seperti mandi, makan, atau melakukan 
pekerjaaan yang menyenangkan. Dan mengembangkan harapan untuk sembuh dan penyakit tersebut tidak terjadi serangan ulangan

2. Quality of life pada pasien sesudah stroke Peneliti menemukan dominan responden berada pada kondisi quality of life yang tinggi. Kondisi tersebut sejalan dengan penelitian Hidayati (2018), yang menyatakan bahwa quality of life pada pasien sesudah stroke di poli saraf RSD dr Soebandi Jember sebagian besar memiliki kualitas hidup baik. Penelitian lain yang mendukung yaitu penelitian dari Brillianty (2015), yang menyatakan quality of life yang tinggi dapat berpengaruh terhadap psikologis juga meningkatkan fungsi sosial dan peran pasien sesudah stroke sehingga pasien merasa lebih bermakna didalam menjalani kehidupan sehari-hari.

Menurut teori Sarafino \& Smith (2011), quality of life yaitu kemampuan sesorang dapat menilai dirinya bahagia dan kehidupanya berguna bagi orang lain. Putri \& Permana (2011) juga berpendapat bahwa kualitas hidup adalah suatu konsep multidimensional yang luas meliputi domain fungsi sehari-hari seperti fungsi fisik, fungsi sosial dan peran, pemahaman terhadap kesehatan. Selain itu menurut Brett, Gow,Corley, Pattie, Starr \& Deary (2012), quality of life sebagai hal yang utama dalam hidup seseorang yang merupakan kesatuan makna antara kebahagian, relasi dalam masyarakat, mampu melaksanakan kegiatan sehari hari dan memilki harapan hidup.

Pengamatan yang didapatkan selama penelitian yaitu faktor yang mempengaruhi quality of life adalah ekonomi, yang mana pasien mengumukakan bahwa biaya pengobatan selama ini seluruhnya mengunakan dana bpjs. Hal ini sangat membantu dalam menangani masalah biaya yang akan di keluarkan ketika akan melakukan pemantauan kesehatan difasilitas pelayanan kesehatan yang telah disediakan pemerintah dan menjalani terapi-terapi serta mendapatkan obatobatan contohnya obat anti hipertensi dalam jangka panjang.

Faktor lain yang mempengaruhi quality of life adalah dukungan sosial, dalam hal ini dukungan keluarga dan juga orang-orang terdekat dari pasien yang selalu memotivasi serta membantu pasien dalam bentuk perhatian dan menemani selama perawatan, dan ada beberapa keluarga yang menyediakan instrumen yang dibutuhkan dalam proses kesembuhan seperti alat-alat bantu berjalan. Hal ini sejalan dengan penelitian Hafdia (2018), yang menyatakan bahwa ada hubungan antara dukungan keluarga dengan kualitas hidup pasien sesudah stroke di RSUD Kabupaten Polewali Mandar.

Melihat latar belakang suku keluarga pasien semuanya berasal dari Sulawesi yang masih memegang teguh budaya dan nilai-nilai gotong royong, sehingga menimbulkan rasa tanggung jawab keluarga untuk membantu dalam proses perawatan. Hal ini terlihat dari keluarga besar yang turut ikut campur tangan dalam memberikan bantuan dan dukungan yang akan diberikan kepada pasien dan proses perawatan yang berlangsung. Keluarga pasien yang lain juga tetap melakukan tradisi dengan datang berkunjung ke rumah pasien untuk membantu perawatan. Hal ini dilakukan dengan tujuan yang sama, yaitu menghibur dan meringankan beban pasien yang melewati masa sulit.

Kurniawan, dkk. (2017), menyatakan bahwa dukungan keluarga yang baik dapat memberikan memotivasi pasien sesudah stroke untuk melakukan program-program terapi dalam menjalani rehabilitasi fisik, sehingga mempengaruhi motivasi dari dalam diri pasien untuk melakukan perilaku yang baik dalam proses kesembuhannya. Hal ini sejalan dengan pendapat Wurtiningsih (2012) ;Pongantung H., Anita Sampe, dkk (2018) mengemukakan bahwa support anggota 
keluarga yang kuat, mempengaruhi motivasi pasien untuk sembuh dan membantu pasien beripikir postif tentang dirinya sedangkan individu yang memiliki rasa rendah diri akan merasa tidak percaya diri, putus asa, dan merasa tidak berguna.

Menurut asumsi peneliti, bahwa pasien sesudah stroke harus memiliki kesadaran pentingnya latihan aktifitas fisik, mengembangkan pikiran positif dan tetap membangun hubungan sosial dengan keluarga inti dan sekitarnya. Pasien yang memiliki motivasi dan keyakinan yang baik akan terus meningkatkan derajat kesehatannya, sehingga diharapkan mampu mengelola dirinya sendiri misalnya pasien dapat melaksanakan aktifitas setiap hari minimal untuk dirinya dan orang disekitarnya dengan demikian pasien merasa hidupnya berguna bagi orang lain. Selain itu keluarga juga berperan sangat penting dalam mendukung anggota keluarga yang menderita stroke, motivasi dan pendampingan seluruh anggota keluarga dapat mengembangkan rasa percaya diri dan pikiran yang positif tentang dirinya dengan demikian pasien akan memiliki semangat untuk melaksanakan proses latihan fisik dan menjalani proses perawatan serta pengobatan agar proses kesembuhan lebih cepat dan quality of life dapat meningkat.

3. Hubungan self efficacy dengan quality of life

Menurut teori Kott (2008), self efficacy mengarahkan seseorang memandang persoalan dari sudut positif sehingga membantu dalam menentukan pilihan dalam bertindak dan komitmen dalam menjalankan pilihan yang dipilih ..

Penelitian yang dilakukan Jones (2011), dilaporkan bahwa self efficacy pasien dengan stroke berhubungan dengan proses penyembuhan pasien stroke dan meningkatnya quality of life dan menurunya depresi. Pandangan ini sesuai penelitian Boger (2014), mengemukakan bahwa self management dapat membantu menyelesaikan masalah misalnya perubahan fisik dan kebiasaan baru yang penuh keterbatasan sesudah stroke .

Hal ini sejalan dengan penelitian Shoufiah \& Noorhidayah (2017), hasil penelitian menunjukkan bahwa terdapat hubungan yang signifikan antara self efficacy dengan kualitas hidup pasien penyakit jantung koroner, responden yang memiliki self efficacy baik memiliki kualitas hidup baik. Hal ini menunjukan bahwa apabila individu mempunyai self efficacy baik maka kualitas hidupnya juga baik. Penelitian lain yang mendukung adalah penelitian Amalia (2016), yang menyatakan bahwa ada hubungan antara self efficacy dengan quality of life pada pasien chronic kindney diseases.

Menurut asumsi peneliti bahwa responden yang memiliki self-efficacy sedang + tinggi dengan quality of life tinggi dikarenakan ada beberapa faktor yang mendukung seperti usia, tingkat pendidikan dan juga faktor psikologis. Pasien sesudah stroke yang memiliki usia dewasa, memiliki pandangan bahwa penyakit dapat terjadi pada setiap orang terutama pada usia tua dan lebih menerima kondisi penyakit yang di derita. Tingkat pendidikan pasien sangat penting dalam menyelesaikan permasalahan dimana latar belakang pendidikan yang memadai akan lebih cepat menganalisis informasi yang diperoleh berdasarkan fakta dan pasien yang mampu mengelolah stres dengan baik akan dapat mengatasi masalah dan lebih yakin bahwa dirinya akan berhasil dan mampu untuk menyelesaikan sesuatu. Pasien yang memiliki motivasi untuk sembuh dapat dilihat dari sikap dan juga usaha pasien yang terus menjalani terapi dan pengobatan untuk proses kesembuhannya. Pendapat lain mengatakan bahwa self-efficacy yang rendah dapat berpengaruh pada kualitas diri seseorang (Amalia,2016) dan didukung oleh hasil penelitian Wakhid, Estri \& Liyanovitasari (2018), yang mengatakan hal ini 
dikarenakan pasien tidak mempunyai keyakinan akan sembuh, pasien tidak dapat menerima kondisinya sekarang, tidak dapat beradaptasi dengan keadaan dan hal itu dapat mempengaruhi kualitas hidup dari segi fisik, psikologis, sosial maupun lingkungan yang mana keempat domain tersebut tidak terpenuhi secara baik.

Menurut asumsi peneliti, kelemahan fisik yang dialami seseorang sesudah stroke kemungkinan menyebabkan terjadinya gangguan psikologi yang merupakan stressor yang dapat menimbulkan perubahan efikasi pada dirinya, ketika self efficacy rendah pasien tidak memiliki keyakinan untuk dapat melakukan sesuatu dengan sukses, sehingga memiliki motivasi yang kurang untuk terus berusaha mempertahankan bahkan meningkatkan derajat kesehatannya sehingga pasien tersebut memiliki quality of life yang rendah.

Adapula di temukan self efficacy sedang + tinggi namun quality of life rendah. Menurut Wakhid, Estri \& Liyanovitasari (2018), bahwa seseorang walaupun memiliki self efficacy baik tidak selamanya memiliki quality of life baik. Hal ini sejalan dengan penelitian Shoufiah \& Noorhidayah (2017), mengatakan seseorang yang memiliki self efficacy baik tidak selamanya memilki quality of life baik, hal ini dikarenakan faktor fisik, yaitu terjadinya perubahan bentuk tubuh, keterbatasan gerak sehingga berpengaruh pada kualitas hidupnya.

Pandangan peneliti bahwa factor lain yang mempengaruhi quality of life adalah kesejahteraan spiritual. Pendapat ini didukung oleh Sriyanti N. P, Warjiman \& Basit, M (2016), mengemukakan bahwa kesejahteraan spiritual tinggi dapat meningkatkan quality of life sesudah stroke di Ruang Poli Saraf RSUD Ulin Banjarmasin, kondisi ini mengartikan semakin baik kesejahteraan spiritual seseorang maka quality of life seseorang semakin baik pula. Aspek lain yaitu Activity Daily Living (ADL), seseorang yang cepat beradaptasi dengan keterbatasanya melakukan kegiatan setiap hari secara mandiri akan berpengaruh terhadap kualitas hidupnya lebih baik. Hal ini didukung oleh penelitian Linggi, E. B, Alfani, K \& Lembang, M. (2018), mengemukanan bahwa Ada hubungan Activity Daily Living (ADL) dengan quality of life pasien sesudah stroke. Kegiatan setiap hari misalnya mandi, makan ,berjalan, dan buang air besar kekamar mandi merupakan kegiatan dasar untuk memenuhi kebutuhan setiap hari untuk dapat bertahan hidup .

\section{KESIMPULAN}

Kesimpulan penelitian ini bahwa self efficacy dapat meningkatkan Quality of life sesudah stroke. Self efficacy yang tinggi pada pasien sesudah stroke, akan meningkatkan rasa percaya, dan semangat untuk sembuh sehingga Quality of life menjadi lebih baik

\section{REFERENSI}

Amalia, V. R., \& Sulistyarini, I. R. (2016). Hubungan Antara Efikasi Diri Dengan Kualitas Hidup Pasien Gagal Ginjal Kronis.

Anasulfalah, H. (2018). Hubungan Self Efficacy Dengan Kualitas Hidup Pasien Dengan Chronic Kidney Disease Yang Menjalani Hemodialisa Di RSUD DR. Moewardi.

Anita, F., Pongantung, H., Ada, P. V., \&Hingkam, V. (2018). Pengaruh Latihan Range Of Motion Terhadap Rentang Gerak Sendi Ekstermitas Atas Pada Pasien Pasca Stroke Di Makassar.

Arsyta, S. (2016). Hubungan Dukungan Keluarga Dengan Self Efficacy Pada Pasien Dengan Penyakit Stroke Di Ruang Rawat Jalan Poli Saraf Rumah Sakit Umum Daerah Sultan Syarif Mohamad Alkadrie Kota Pontianak.Retrieved Oktober 13, 2019.

Arum, S. P. (2015). STROKE, Kenali, Cegah \& Obati. Yogyakarta: Notebook. 
Boger. (2014). Self-Managent Following Stroek.Concept and Measurement. Retrieved February 27, 2020, from https://epr ints.soton.ac.uk/362824/1/Final\%2520Thesis. pdf

Breet, C. E., Gow, A. J., Corley, J., Pattie, A., Starr, J., \& Deary, I. J. (2012). Phychosocial Factors and Health as Determinants of Quality of Life Research21(03)505516. Retrieved Oktober 1 0, 2019,

Brillianti, P. A. (2015). Hubungan Self Management dengan Kualitas Hidup Pasca Stroke di Wilayah Kerja Puskesmas Pisangan Ciputat. Retrieved Oktober 3, 2019, from http://repository.uinjkt.ac.id

Feist, J., \& Feist, G. J. (2010). Teori Kepribadian (Terjemahan Smita Prahita Siahputri). Jakarta: Salemba Humanika.

Hadiati, D. (2014). Uji Validitas dan Reabilitas Stroke Specific Quality of Life (SSQoL) Berbahasa Indonesia Pada Pasien Stroke. Retrieved Oktober 25, 2019.

Hafdia, A. N., \& dkk. (2018). Analisis Kualitas Hidup Pasien Pasca Stroke di RSUD Kabupaten Polewali Mandar. Retrieved February 27, 2020, from http://jurnal.yapri.ac.id

Hidayati, K. (2018). Hubungan Pemenuhan Aktivitas Kehidupan Sehari-Hari dengan Kualitas Hidup Klien Pasca Stroke di Poli Saraf RSD dr. Soebandi Jember. Retrieved Oktober 25, 2019, from https://repository.unej.ac.id

Howsepien, B. A., \& Merluzzi. (2009). Religious Beliefs, Social Suport, SelfEfficacy and Adjusment to Cancer. PsychoOncology18: 1069-1079. Retrieved February 27, 2020, from www.interscience.wiley.com

Ismatika, \& Soleha, U. (2017). Hubungan Self Efficacy Dengan Perilaku Self Care Pasien Pasca Stroke di Rumah Sakit Islam
Surabaya . Retrieved Oktober 2019, from http://journal.unusa.ac.id/index.php/jhs/articl e/viewFile/418/404

Jones, F., \& Patridge, C. (2008). The Stroke Self-Efficacy Questionnaire: measuring individual confidence in functional performance after stroke. Retrieved September 5, 2019.

Jones, F., \& Riazi, A. (2011). Self Efficacy and Self Management After Stroke : A Systematic Review. Disability and Rehabilitation. Retrieved Oktober 19, 2019, from

https://www.ncbi.nlm.nih.gov/pubmed/20795 919

Junaidi, I. (2011). STROKE : Waspadai Ancamannya. Yogyakarta: ANDI.

Koot, H. M. (2008). Early Parenting Intervention : Family Risk and First Time Parenting Relatet to Intervention Effectivvenes. Retrieved February 27, 2020, from https://research.vu.nl/ws/portalfil es/portal/2330910/stok+journal++of+child+a nd+family+psychologi+17+2008+u.pdf

Kurniawan, \& dkk. (2017). Hubungan Dukungan Keluarga dengan Kepatuhan Rehabilitasi Fisik Pasien Stroke. Retrieved February 27, 2020, from http://repository.umy.ac.id

Latifah, M. (2016). Hubungan Self Efficacy dengan Perilaku Self Care Pasien Kanker Payudara di Rumah Sakit Ongkologi Surabaya. Retrieved February 27, 2020, from http://repisitory.unusa.ac.id/362/1/SRKP160057 abstract.pdf

Lemone, P. (2016). Buku Ajar Keperawatan Medical Bedah Gangguan Neurologi Diagnosis Keperawatan NANDA PilihanNic Noc Edisi 5. Jakarta: EGC.

Linggi, E. B, Alfani, K \& Lembang, M. (2018). Hubungan Activity Daily Living (ADL) dengan Kualitas Hidup Pasien Pasca 
Stroke di Ruang Fisioterapi RSUP DR. Wahidin Sudirohusodo Makassar. Retrieved Maret 2020, from

http://ejournal.stikesnh.ac.id/index.php/jikd/a rticle/download/872/730/

Masniah. (2017). Kualitas Hidup Pada Pasien Pasca Stroke di RSUD Ulin Banjarmasin. Retrieved Oktober 22, 2019, fr om https://ojs.dinamikakesehatan.unism.ac.id /index.php/dksm/article/view/234/178

Pertamita, M. D. (2017). Hubungan Efikasi Diri dengan Kemandirian Aktivitas Seharihari Pada Pasien Stroke di RSUD Tugurejo $\begin{array}{lll}\text { Semarang dan RSUD } & \text { K.R.M.T }\end{array}$ Wongsonegoro. Retrieved September 14, 2019, from http://eprints.undip.ac.id/54649/pdf

Pukeliene, V., \& Starkauskiene, V. (2011). Quality of Life : Factors Determining its Measurement Complexity. Retrieved Oktober 19, 2019.

Pongantung, H., \& Sampe, A. May lanny, Meyer (2018) Hubungan Dukungan Keluarga dengan Self Efficacy pada Pasien Stroke di RSU Dr. Wahidin Sudirohusodo Makassar. ejurnal. stikmakassar. ac. id.

Putri, W. A., \& Permana, I. (2011). Hubungan Antara Fungsi Keluarga dengan Kualitas Hidup Lansia di Kelurahan Wirobrajan Yogyakarta.

Ratnawati, N. (2016). Hubungan Efikasi Diri Terhadap Kualitas Hidup Pasien Diabetes Militus Tipe 2 di RS PKU Muhammadyah Yogyakarta.

Rendy, C. M., \& TH, M. (2012). Asuhan Keperawatan Medikal Bedah Penyakit Dalam. Yogyakarta: Nuha Medika.

RISKESDAS. (2018). Kementerian Kesehatan Badan Penelitian dan Pengembangan Kesehatan. Retrieved September 14, 2019.
Rustika, I. M. (2012). Efikasi Diri : Tinjauan Teori Albert Bandura. Retrieved February 27, 2020.

Sarafino, E. P., \& Smith, T. W. (2011). Health Psychology : Biopsychosocial Interaction 7th ed. New York: John Wiley \& Sons. Retrieved Oktober 14, 2019,

Selatan, P. K. (2015). Retrieved Oktober 19, 2019, from http://www.depkes.go.id/resource s/download/profil/PROFIL KES PROVINSI 2015/27 SulSel 2015

Shoufiah, R., \& Noorhidayah. (2017). Efikasi Diri Berhubungan Dengan Kualitas Hidup Pasien Penyakit Jantung Koroner. Retrieved February 27, 2020.

Smeltzer, S. C. (2013). Keperawatan Medikal-Bedah Brunner \& Suddarth Edisi 12. Jakarta: EGC.

Sriyanti,N. P., Warjiman \& Basit, $\quad$ M. (2016). Hubungan Kesejahteraan Spiritual Dengan Kualitas Hidup Pasca Stroke. Retrieved Maret 2020, from https://pdfs.semanticscholar.org/87c1 /d2161d0f0c78c6e3edd299551b73c718c6af.p df

Wakhid, A., Estri, L. W., \& Liyanovitasari. (2018). Hubungan Efikasi Diri dengan Kualitas Hidup Pasien Gagal Ginjal Kronik yang Menjalani Hemodialisis. Retrieved February 27, 2020, from http;//jour nal.ummgl.ac.id/index.php/nursing/article/do wnload/2430/1346

WHO. (2016). WHO Global Report : MortalityAttribute to Tobacco. Geneva, Word Health Organization. Retrieved September 2 6, 2019, from http://www.wpro.who.int/china /topics/tobacco/tbs-2016-en

Williams, S. L. (2018). Development of a Stroke-Spesific Quality of Life Scale. Retrieved Oktober 25, 2019, from https://ww w.researchgate.net/publication/12909528 
Wurtiningsih, B. (2012). Dukungan Keluarga

Pada Pasien Stroke. Semarang

Medica Hospitalia. Retrieved February 27, 2

020, from http://medicahospitalia.rskariadi.co .id

Yantik. (2014). Efikasi Diri Pada Pasien Strokr di Poli Syaraf di Rumah Sakit Dr.Abdoer Rahem Situbondo. Retrieved Okto ber 14, 2019. 